\title{
A FELISMERÉS ÉS \\ ANNAK 23-FÉLE TÁMOGATÁSA
}

\begin{abstract}
A tudományos haladásban fontos lépés a megismerés, de nem feledkezhetünk meg a felismerésról, azaz a mentális folyamatokról sem. A tudományelméleti megállapítások, amelyek valamely kérdés megalapozottságára, a tudás és ismeret objektivitására vonatkoznak, döntốen a megismerés folyamatát érintik. A szerzố írásának középpontjában azonban a felismerés áll.
\end{abstract}

\section{Kulcsszavak: tudományos munka, publikálás, felismerés}

Ha tudományos munkákat olvas az ember, általános tapasztalat a rengeteg hivatkozás, forrás, irodalmi megalapozás. Kis túlzással mondhatni, hogy néha egyegy értekezésben több oldalt tesz ki a forrásjegyzék, mint maga a munka érdemi része. Ez nemcsak szokás, de követelmény is. A doktori iskolák kutatás-képzési programjaiban pl. nagy szerepe van a szakirodalommegismerésnek, -feldolgozásnak, idézési és hivatkozási módszereknek. Tudományos fokozat elbírálásakor jelentôs szempont a források kezelése, a hivatkozás, az értekezés szakirodalmi „felöltöztetése”. Alig lehet olyan elméletileg is értékes szakpublikációt találni, amelyik nem bővelkedik mások ismereteinek használatától. A szabad, önálló, hivatkozási apparátus nélküli megnyilatkozás mintha értéktelen vagy divatja múlt lenne. Csak néhány szerkesztôség és szerzô vállalja, hogy jó szakírásokat közöljön „,meztelenül”.

Ezt az írást tanulmánynak nevezzük. Lehetne közleménynek, értekezésnek vagy esszének is minősíteni. A kifinomult tudományelméleti szakértók számára mindezek a fogalmak eltérő tartalmat jelentenek. Már az elnevezések és a hozzájuk köthető értelmezések sokfélesége is jelzi, hogy - a tudományos fontoskodáson túlmenően - lényeges lehet az is, hogy egy írást minek tekintenek. Erre már csak azért is érdemes utalni, mert a továbbiakban egy ennél fontosabb kérdést, a tudományos írásmú, sôt gondolat születésének természetét fogjuk elemezni. Tudni lehet ugyanakkor, hogy a tudományelmélet vagy a tudománymetria számára az írás múfaja éppenséggel alapkérdés. Nem kívánunk az ezen szakterületeken folyó elméleti vitákba szerepet vállalni, már csak azért sem, mert érdeklődésünk nem erre irányul.
Szúkebb szakterületünk, a vezetéstudomány egyik alapvetése, hogy megfigyelésekre épít. A tudományos relevanciához e területen azonban nem elég a megfigyelt valóság elemeiból felépíthetố logikai megfelelóség. Azokat szokták jó, elméletileg is alátámasztott vezetési megoldásoknak tartani, amelyek kiállják a gyakorlat próbáját. Különös ellentmondás, hogy a társadalomtudományokban általában nem elegendố a megfigyelésekre épülő megismerés folyamatának kialakult és elfogadott volta. A nagyon sokféle tényező és eltérô hatásmechanizmus együttes érvényesülése miatt a megfigyelések csak korlátozottan nyújtanak támaszt a jelenségek megismeréséhez, megértéséhez és a jövőbeni magatartás megalapozásához. A társadalomtudományokban egyébként is kétséges, hogy lehet-e nagy bizonyossággal olyan megállapításokat tenni, amelyek a jövơre is érvényesek.

Ha például folyamatok általános életgörbéit tanulmányozzuk, akkor megállapítható, hogy mindig van hanyatló szakasz. Ebból akár arra is lehetne következtetni, hogy maga a társadalom mint képződmény is egyszer el fog jutni egy hanyatló, akár eltúnő korszakba. Ezt azonban csak mint elméleti lehetôséget szokták bemutatni. A társadalomtudósok azon gondolkodnak, miként lehetne a végzetszerú hanyatlást elkerülni, vagy legalábbis elhalasztani. A korlátozott racionalitás többek között rámutat az eredmények azonos feltételek közti megismételhetőségének kérdőjeles voltára. Ez pedig rá kell, hogy irányítsa a figyelmet a társadalomtudományokban a megfigyeléseken alapuló elemzés gyengeségeire. Ilyen körülmények közt a felismerések felértékelődnek. Más közegben a felismerések jelentő- 
sége másodlagosnak túnhet, de pl. a vezetési gyakorlatban elég erôteljes az érvényesülésük. Nem elegendó ugyanis más - bár hasonló - helyzetek tapasztalata a jó megoldások megtalálásához. Ehhez többnyire még felismerés, invenció és kezdeményezés is kell.

Ezt tükrözik az üzletpolitikától a kormánypolitikáig jellemző vezetési tapasztalatok. Változékony feltételek közt a reálfolyamatok, társadalmi mozgások tényleges vonásainak ismerete mellett egyre nagyobb szerepet kap a felismerés. A megfigyelés nem ad elégséges alapot sem a folyamatok megismeréséhez, sem a cselekedetekhez. A felismeréseket azonban gyakran voluntarista módon, vezetôi vagy politikai szándék csomagolására használják. Sem etikai, sem tudományossági megközelítésben nincs alapja annak, hogy szándékokat, politikai célokat úgy tüntessenek fel, mint a változások természetének, irányának „,felismerését”. Ez közönséges hamisítás, ami a politikában megszokott, az üzleti gyakorlatban káros, a tudományban pedig elfogadhatatlan.

Üzleti és közéleti vezetók igen gyakran nem a reális folyamatok megismerésén, ismeretén alapuló döntéseket hoznak. Álláspontjukat szándékok mentén alakítják ki. A politikai vezetés tudatlanságaiból vagy rossz szándékaiból következő példák ismertetésétól itt eltekintve utalni lehet néhány üzleti jelenségre. Ezekról sok esetben megállapítható, hogy a tényleges körülmények, lehetôségek - vagyis a megfigyelhetố jelenségek - nem játszhattak meghatározó szerepet a döntéshozatalban. Ezek elsôsorban a sikertelen akciók. Ilyen az elmúlt másfél évtized hazai gazdaságtörténetében a privatizáció számottevố része, a vállalkozásalapítások többsége, a felvásárlásoknak a remélt előnyöket (szinergiákat) meg nem valósító, mértékadó hányada, a támogatásokkal célzott eredmények (pl. foglalkoztatottság növelése) elérésének alacsony szintje stb. Az említett gazdasági múveleteket a nagyobb léptékúek közé lehet sorolni. Mellettük számtalan apróbb gyakorlati hiba is ismert, melyeket leegyszerúsítve többnyire vezetési problémának szoktak nevezni. Jelen írásunk célja annak elfogadtatása, hogy ha már nem a tények ismeretén (értelmezésünkben: a megismerésen) alapulnak a döntések, akkor legalább a felismerések (és ne pusztán megalapozatlan szándékok) támogassák azok helyességét.

Sok sikertelennek bizonyult vezetési aktus hátterében a körülmények alapos megismerése aligha állhatott. Ugyanakkor döntések, akciók mégis születtek. Ezek arra utalnak, hogy a megismerés klasszikus módszerei mellett más, intuitív és innovatív - egyben nagyobb hibakockázatú - módszerek is használatosak. Ezeket jó esetben felismeréseknek lehet tekinteni. A felismerések bevonultak a vezetéstudományi gyakorlatba. Ha a döntések objektív, a körülmények megismerésén alapuló megalapozása gyakran elmarad, akkor éppen a felismerési képességek fejlesztése járulhat hozzá, hogy a vezetôi magatartás kapjon több tudományos hátszelet. Ennek támogatását is szolgálni kívánja tanulmányunk.

Érdekes paradoxon, hogy szúkebb tudományterületünkön, a vezetés és szervezéstudományban is egyre általánosabb, mondhatni uralkodó nézet, hogy megfigyeléssel, adatokkal, mások véleményével támasztjuk alá a megállapításokat. Ezek a módszerek meghatározó súlyt fektetnek a megismerésre. A vezetéstudományi kutatások többsége megismerés: a vezetốk tényleges magatartásából indulunk ki. Emellett kevésbé jelentôs a felismerések szerepe. A gyakorlat viszont sokszor nélkülözi a helyzet, a körülmények szisztematikus megismerését. Írásunk a felismerések támogatása érdekében annak természetével, tudományos és gyakorlati hasznosságával is foglalkozik. Ezzel támogatást adunk a megismerésekre kevésbé, a felismerésekre - ha van ilyen - erôteljesebben támaszkodni kívánó vezetốknek.

Tévedés lenne azt gondolni, hogy a felismerés a megismerés primitívebb, a valós viszonyokra kevésbé támaszkodó változata. Írásunkban azt is be fogjuk mutatni, hogy az ismeretszerzésben a felismerés csak más, de nem egyszerúbb, vagy kivált nem rosszabb módszer, mint a megismerés. A kettố egymást kiegészítheti vagy cáfolhatja, akárcsak minden más ismeretszerzési módszer vagy tudás. Bolyai felismerése a nem euklideszi geometria természetéról nem rontotta vagy gyengítette az euklideszi világképet. Egyszerúen többet lehetett tudni a geometriáról Bolyai által, mint nélküle.

E tanulmány megírására azért került sor, mert be kívántuk mutatni: a tudományos munkákban elvárt és szokásos hivatkozási, idézési támasztékok módszere mellett mindezek nélkül, a felismerések erejével is lehet új, tudományos értékú megállapításokat tenni. Az idézések, utalások fontosságát nem vitatva ki kell állni azok mellett a tudományos értékek mellett is, amelyek nem használják ezeket a módszereket.

\section{A vizsgált probléma}

Álláspontunk pontosítása érdekében összefoglaljuk, hogy milyen megállapítások tekinthetók tudományos értékúnek:

1. A megállapítás tényszerú kell, hogy legyen. Kitalációk nem tekinthetók tudományos megállapításnak. A sejtések, feltételezések azonban tudományos értékúek lehetnek, ha azokat valós összefüggések alapján teszik és igazolhatók is.

2. Az összefüggések tényszerúségét is igazolni kell.

3. Az igazolásokat, bizonyításokat lehetőleg többféle 
- egymástól eltérő - módon kell megtenni. Ilyen például a trianguláció, és minden más, sokirányú megközelítés alapján történó igazolás.

4. Rögzíteni kell, hogy milyen körülmények és feltételek közepette érvényesek a megállapítások.

5. A megállapításoknak megismételhetónek, azaz az elfogadott körülmények közt más (akár minden) esetekben is érvényesnek kell lenniük. Ez utóbbi követelmény a társadalomtudományok sok területén csak korlátozottan igaz. A történelemben pl. nincs lehetôség az események megismétlésére, legfeljebb hasonlóságokat lehet megállapítani. A vezetéstudomány számára ismert, hogy ha valamilyen problémamegoldás eredményes volt, az nem biztosíték arra, hogy más, hasonló probléma kezelésekor ugyanaz a módszer ismét sikerre vezet.

A fenti feltételeknek megfelelô megállapításokat tekintik bizonyított, tehát elfogadható tudományos tételnek. A bizonyítás önmagában bonyolult múvelet. Lehet egy tétel logikai, elméleti és tapasztalati evidencia. A megállapításoknak társadalmi függósége is van (ezzel foglalkozik pl. a tudományszociológia). A kor és a körülmények nagy szerepet játszanak a tudományos tételek megfogalmazásában és még érvényességében is. Ez kivált a társadalomtudományokban figyelhetô meg.

A bizonyítást (jusztifikálásnak, igazolásnak is nevezik) általában az adott tudományágban elfogadott módszerek szerint teszik meg. Összességében logikai ítéletalkotásnak lehet nevezni, amelynek kifinomult szabályai és szokásai ismertek. A megállapítások tudományossága azt is jelenti, hogy a bizonyítás során néhány szokásnak, érvényességi próbának eleget kell tenni. Ilyen az oksági összefüggések, a szükséges és elégséges feltételek megállapítása. Ide sorolják a definiálást, az osztályozást - ami egyben kiválasztást is jelent -, a következtetést és az általánosítást. Ezeken belül is kiemelt jelentősége van a kvantitatív és a logikai igazolásoknak. A logikai igazolások két pillérre épülnek: a premisszákra és a deduktív vagy induktív következtetésekre. Amennyiben mindezen követelményeknek valamely megállapítás eleget tesz, akkor azt tudományosan is értékelhetőnek szokták tekinteni. Nehéz, igényes munka tudományos megállapításokat tenni.

A vezetéstudomány számára gyakorlati jelentősége van annak, hogy a vezetối és a szervezeti magatartást milyen tényezók befolyásolják. Ezek közt fontos - bár messze nem kizárólagos - szerepe van az objektív helyzetról kialakított véleményeknek. Ezek alapja többnyire az ismeret, a tudás, amit különféle módon lehet megszerezni. (Megjegyezzük, hogy az ismeretek mellett az érzelmek és az etikai megfontolások is jelentôs szerepet játszanak a magatartásformálásban.) Korunkra jellemző́, hogy az üzleti közösségekben a tudományos ismereteket nagymértékben kvantitatív tulajdonságúnak, mérhetőnek, adatokkal jellemezhetőnek szokták tekinteni. Ennek elismerése mellett mi a figyelmünket, és ezzel ismeretszerzési érdeklődésünket is a kvalitatív, közvetlenül nem mérhető folyamatok, jelenségek felé irányítjuk. Ugyanakkor nem állítjuk, hogy a megfigyelés eredménye kvantitatív, hiszen a kvalitatív kutatások, tapasztalatok is meghatározó ismeretforrások.

Az ismeretek megszerzése általában nem csak megismerés eredménye. Maga a tudás lehet tudományos vagy tapasztalati termék, de lehet a megértés, azaz szellemi tevékenység eredménye is. Ilyen a (nem pejoratív értelmú) spekuláció, amelyik tisztán mentális, logikai folyamat. Természetesen a tudományos gondolkodás is része a megértésnek és viszont. Kölcsönhatások láncolata jellemzi a tudást és az ismeretszerzést.

\section{A megfigyelésekból levonható hibás következtetés}

A társadalmi viselkedéssel foglalkozó kutatások meglehetôsen egyöntetú tapasztalata, hogy a skandináv országokban viszonylag alacsony a korrupciós fertôzöttség. Jelentősek a megvesztegetési problémák viszont az afrikai országok körében. Ebbő́l a két megismert körülményből arra a következtetésre is lehetne jutni, hogy a korrupció és az éghajlati viszonyok közt szoros kapcsolat van. Nem vitás, hogy ennek számtalan jelét kihasználva akár tudományos elméletet is lehetne erre az összefüggésre alapozni. (Ez egyébként meg is történt. Montesquieu a Törvények Szelleme címú alapmúvében az éghajlat, nép és társadalom alakító szerepérôl értekezett. Ennek részeként a fizikai és szellemi adottságokat a népek vérmérsékletére vezette vissza, ebból következően hiedelmeikkel és erkölcseikkel hozta öszszefüggésbe. A torz politikai magatartást hamis érvekkel támogató fajelméletekben is gyakorta felbukkantak az éghajlati komponensek. Hofstede is rámutat arra, hogy a kultúraváltozók varianciájának egyik legerôteljesebb magyarázó tényezôje az egyenlítôtól való távolság, ami számszerúen igazolható.)

Ugyanakkor - legalábbis számunkra - kézenfekvő, hogy a korrupció és az éghajlat közvetlen összekapcsolása butaság. Noha a jelenség és az ebból eredó következtetés logikailag fennállhat, de a megfigyelt helyzet természete alapján ezt az összefüggést mégsem kell meghatározónak, vagy akár csak komolynak is tekinteni. A probléma, amelyet vizsgálunk tehát az, hogy a jelenségek, folyamatok megfigyelése, értékelése, elemzése mennyire elegendő forrás tudományos értékú megállapításokhoz. 
A fentebb említett extrém és karikírozó példa, vagyis a korrupció éghajlatfüggó jellege az általános követelmények szerint akár bizonyítható is lehetne. Nemcsak Skandinávia és Közép-Afrika, hanem Ausztrália és Latin-Amerika esetében is fennáll a korrupció éghajlat„függő” kapcsolata. Érvényes a megállapítás nemcsak a korrupcióra, hanem az országok politikai irányítására, a piaci folyamatok szervezettségére és a költségvetési redisztribúcióra egyaránt. Az összefüggések több évtized távlatában is helytállóak. Mindezek alapján ki is alakultak a politikai elemzókben és a médiaszócsövekben az (északi féltekére vonatkozó) észak-dél típusú magatartásmintákon alapuló kulturális szembeállítások. Nem lehetetlen tehát, hogy valamely elvakult elemző komolyan vegye az éghajlat korrupciós befolyásoló hatását. (Egyébként az egy fớre jutó GDP és a korrupció közti szoros korreláció megalapozottabb következtetésekhez vezet.) Nagyon erős morális érvek is szólnak amellett, hogy az ilyen megfigyeléseken alapuló feltételezések ne váljanak tudományos tételekké.

A példában szereplő probléma áltudományosnak túnik. A valóságban azonban igen sok esetben találkozni olyan összefüggésekkel, amelyek ugyan a közvetlenül észlelhetố tapasztalatoknak ellentmondanak, de tudományosan igazolhatók. (Sokáig ilyennek számított pl. az, hogy a Föld forog saját tengelye és a Nap körül. Sok esetben a tudományosság sok kritériumát kielégítô megállapításokról nehéz eldönteni, hogy azok helytállóak-e. Ez pedig azon múlik, hogy valódi oksági kapcsolatokat, összefüggéseket állítottunk-e egymás mellé, vagy csak jelenségeket. Kiszélesítve ezt a kérdést: a megismerés elegendő alapot ad-e az ismeretekhez? A tudományos haladásban fontos lépés a megismerés, de nem feledkezhetünk meg a felismerésról, azaz a mentális folyamatokról sem. A tudományelméleti megállapítások, amelyek valamely kérdés megalapozottságára, a tudás és ismeret objektivitására vonatkoznak, döntően a megismerés folyamatát érintik. Írásom középpontjában azonban a felismerés áll.

A megismerhetôség hibáira mutat rá egy közkeletú ellenôrizetlen - adoma. Az időjárás-előrejelzések programjai ezek szerint nagyon sok adatszerú megfigyelésre támaszkodnak. Az idójárást befolyásoló több tucat múltbéli és valós idejú megfigyelés adataiból szokták a meteorológiai prognózisokat finomra hangolt modellek szerint elővarázsolni. A rossznyelvek szerint azonban, ha elvégeznek néhány ellenôrző kísérletet, akkor meglepó eredményre jutnak. Amennyiben valamely múlt idôszak előrejelzés-készítéshez szükséges jellemzô valamennyi adatát betápláljuk a prognóziskészítő programba, akkor annak valószínúsége, hogy a ténylegesen bekövetkezett idójárási jellemzókhöz jutnak, elég alacsony. Úgy is vélekednek az adoma terjesztôii, hogy az idôjárás népi bölcsességeken alapuló előrejelzései (amelyek egyébként a megfigyelések és a vélekedések kevercsei) akár pontosabbak is lehetnek, mint a részletes és soktényezôs megfigyelési rendszerekbool kikövetkeztethetố időjárás. Mindez természetesen csak színesíti, de nem cáfolja a megfigyelések jelentőségét. $\mathrm{Az}$ adomát úgy is értelmezhetjük, mint a megfigyelési és modellezési kockázatok értelmezését.

\section{Néhány fogalom}

A szakácsok ételeket fóznek. Mások - anélkül, hogy kötelező lenne számukra főzni tudni - szakácskönyvet írnak. A szakácskönyv az esetek többségében a főzés megfigyelésébôl és részletekbe menő leírásából áll. Le lehet írni, hogy milyen anyagokból, milyen menynyiségekbő́l, milyen technológiai lépésekből, milyen hô- és idôhatásokból, hogyan kell az ételeket elkészíteni. Azonosítani lehet az ételek állagát, színét, illatát is. Ha az ételek élettani hatásaira is kíváncsi valaki, azt nem a szakácsok, hanem az élelmiszer-vegyészet és az orvostudomány fogalmazza meg. A fentebbi példában a szakács a felfedezô, a felismerô. A szakácskönyvíró a megfigyelő és megismerô, az élelmiszervegyész és az orvos pedig a tudományos elemzó. Elmélkedéseik azonban a szakácstudomány lényegét, az ételek élvezhetôségét alig érintik. Ez a fogyasztóra marad.

Jelen írásban több párhuzamos, gyakran találkozó, egymást részben átfedố fogalmat használunk. Az első a megismerés, a második a felismerés, a harmadik a megértés, negyedik a megfigyelés. Az első kettô szoros rokonságban áll egymással. Vannak, akik úgy vélik, a megismerés része a felismerés, mások ezt épp fordítva értelmezik. Mi a két fogalom elkülönítésére, eltérő jellegére utalunk. A megértés is távoli rokona, bizonyos értelemben következménye az előbb említett fogalompárnak. A megfigyelést leginkább mint a megismerés és a felismerés egyik forrását lehet értelmezni. Mindezeket a fogalmakat a tudás kialakítása, megszerzése részeként értelmezzük. A tudás több, mint ismeret. Tudás alatt a tudományosan is értékelhetố ismeretet értjük.

A megismerés a körülöttünk lévő világ jelenségeit, folyamatait fordítja le számunkra. A felismerés ugyan ezt teszi, de nemcsak szisztematikus kutatómunka, hanem nagyrészt mentális folyamat révén. A megértés ugyancsak mentális folyamat: a megismert vagy felismert jelenségek, összefüggések beillesztése gondolatés ismeretvilágunk kereteibe, azokhoz kapcsolódása. Amíg tehát a megismerés és felismerés céltáblája a külvilág (beleértve magára a megfigyelőre vonatkozó 
ismereteket is), addig a megértés céltárgya maga az ismeret és a tudás. A megfigyelés a fenti folyamatokat megalapozó, a külvilágra irányuló, arról képet alkotó értelmi folyamat. A mindennapi szóhasználatban a fentebb említett négy fogalmat gyakran keverik.

A felismerés kiemelése e négy fogalom közül számunkra gyakorlati okok miatt indokolt. Mint a bevezetốben utaltunk rá, a tudományos gondolkodást jól körülhatárolt feltételekkel, módszerekkel, követelményekkel körbebástyázott tevékenységnek tekintjük. A megismerés ennek része, azaz a folyamat, amely elvezet a tudományosan is értékes eredményekhez. A tapasztalatok szerint azonban akár tudományosan is elfogadható, akár gyakorlatilag hasznos eredményekhez akarunk eljutni, akkor a szisztematikus megfigyelések mellett más módszerek is rendelkezésre állnak. Ezek közé tartozik a felismerés. Ez a módszer nem követel meg olyan alapos kapcsolatot a világ jelenségeivel vagy a tudományos háttérrel, mint a megismerés vagy a megfigyelés általában. A tudománytörténet ismer olyan felfedezéseket, amelyeket jószerint semmiféle megfigyelés nem alapozott meg, hanem csak spekulációk eredménye. Ilyen pl. a formális logika tudománya, melynek alapvetéseit elméleti konstrukcióknak is lehet tekinteni. A tapasztalat közvetlenül nehezen igazolja a formális logika megállapításait, téziseit, hiszen azok a gondolkodás rendezését szolgálják. Ugyanakkor igen fontos, hogy tapasztalati módon ezeket nem lehet cáfolni, ami megerôsíti a logikai alapvetések érvényességét. A filozófiai megállapítások többségére is ez a jellemző.

A természettudományok körében - például a fizikában, csillagászatban stb. - ismert a kísérleti és az elméleti tudománymúvelés szétválasztása. A mi értelmezésünkben a kísérleti tudomány a megfigyeléssel, az elméleti tudomány pedig a felismeréssel rokon. Az elméleti tudomány nagymértékben támaszkodik a kísérleti tudomány tapasztalásaira, megállapításaira, de azokból olyan következtetéseket is levon, melyek önmagából a kísérletezésból nem származtathatók, legfeljebb igazolhatók vagy cáfolhatók. Az elméleti tudományok múvelői azonban nemcsak hasznosítják a kísérletezók eredményeit, hanem idônként „megbízásokat" is adnak számukra. Ha ugyanis új megállapításokra jutnak, akkor szükség lehet ezek tapasztalati igazolására is. Nagyjából ez a viszony a megismerés és a felismerés között. A megismerés tekinthetố - társadalomtudományok viszonyai közt - a kísérleti, azaz a tapasztalatokon alapuló módszernek (bár tényleges kísérletezésre többnyire nem is kerülhet sor). A felismerés a társadalomtudományok „elméleti” múvelése, melynek nem csak és nem kizárólag megfigyeléses alapjai lehetnek. A társadalomtudományokban is a ki- gondolt megoldások gyakran bizonyultak tévutaknak. Ezek egy részét szokták utópiának nevezni.

Régebben elegendő volt egy tudományos megállapítás sejtése vagy felismerése, és ezt követte a tétel bemutatása, levezetése. Ma, amikor a megfigyelések szinte kötelező elôzményei a megállapításoknak, általában nehezen elfogadható, ha egy tudós csak kijelent valamit, és ezek után nekilát a bizonyításnak. Elvárt, hogy már sejtéseit, hipotéziseit is megfigyelésekkel támassza alá. A kijelentést, megállapítást így szinte megelózi a megfigyelés, ami egyébként maga is a bizonyítás egyik formája, társadalomtudományokban annak fontos része.

A megfigyelés szokása, mondhatni követelménye azt is jelenti, hogy hivatkozni kell a pályatársak vagy más tudományos megállapítások bizonyító, igazoló, megerősítő voltára. A megállapítások értékét a mára szinte önállósodott tudománymetria módszereivel is erôsíteni szokták. Ha például egy közleményt sokan hivatkoznak vagy idéznek, akkor az növeli annak tudományos rangját, „értékét”. Az idézettség önmagában is tudományos értékmérôvé vált. Ezzel a marketing bevonult a tudomány eredményeinek minősítésébe. Amely gondolatot jól sikerült eladni - azaz gyakran utalnak rá -, az önmagában fontosnak, értékesnek tekinthetô. Némely kutatókat ez arra is serkent, hogy jól eladható (hivatkozható) megállapításokat tegyenek - azaz pl. botrány- vagy szenzáció-jellegú publikációkat alkossanak. A tudósképző doktori iskolák alapvetô módszerei közé tartozik, hogy a növendékek fejlesszék és bizonyítsák jártasságukat, olvasottságukat, és felkészüljenek gondolataik tetszetôs, eladható megfogalmazására. Ez is a megfigyelés része. A doktori tézisek minősítési folyamatában a tartalmi elemek mellett igen sok prezentációs követelmény is hangsúlyossá válik. Ha mások vélekedésének megfigyeléséról vagy értékeléséról van szó, akkor természetesen elengedhetetlen a hivatkozás.

A megfigyelések piaci értéke arra serkent kutatókat, hogy maguk is önállóan eladható piacképes tudományos termékeket állítsanak elô, lehetóleg a legolcsóbban. Őket lehet internettudósoknak nevezni. Mások kutatásait, közleményeit felhasználják, és azokból másod- és sokadlagos - következtetésekkel állnak eló. Igen divatos pl. komoly statisztikai források hivatkozásával, csinos prezentálásával megjelenni tudományos konferenciákon. Az internettudósok (vagyis a mások által megismert vagy felismert eredményekre építkezô) közleményei, hivatkozásai adják ma - konferencia-tapasztalataim szerint - a tudományos közlemények jelentôs részét. Néhány divatos gondolkodási mód szinte serkenti is a mások gondolatait elemző elméletgyártókat. Nem a valóságról, a tapasztalatokról értekeznek, hanem arról, hogy ki mit írt, vagy mit mondott. Vannak 
folyóiratok, amelyek a hivatkozásokat nélkülöző kutatási beszámolókat, az esszéket fanyalogva fogadják, nem tartják elég „értékesnek”.

Mindezek a szokások hozzájárulnak ahhoz, hogy valamely megállapítás tudományosan bizonyított legyen. Tudni lehet azonban, hogy a megismerést nem csak a való világ vagy a tudós irodalom megfigyelésével lehet megalapozni. Erre épül a felismerések fontosságát, szerepét hangsúlyozó nézet. A tudomány nyitva áll a bizonyított felismerések elôtt is. A gyakorlati életben azonban a tudományos bizonyítástól eltérô, mondhatni puhább követelmények érvényesülnek a felismerésekben.

A bizonyítás helyébe gyakran a próba, azaz az utólagos megfigyelés lép: ha valamely felismerés, nézet alkalmazható a gyakorlatban, akkor annak helyességét el szokták fogadni. A vezetéstudomány például a gyakorlati alkalmazhatóságot fontosabbnak tekinti, mint a logikailag kifogástalan érvelést, bizonyítást. Néhány legendás vezetéstudományi tétel, mint a Peters-elv vagy a Parkinson-törvények, szinte kizárólag a gyakorlat próbáján állják meg a helyüket, logikailag az ellenkezójük is bizonyítható lenne. A társadalomtudomány igen sok felismert, az ismert társadalomelméletekból azonban egyértelmúen nehezen levezethetố jelenséget ismer és fogad el, mint pl. a szegregáció, a kasztosodás vagy az elitesedés.

A magyar 1989-es társadalmi rendszerváltás idején igen sok olyan tanulmány született, amely a tervgazdaságból a piacgazdaságba vezető út modellezésére vállalkozott. Ezeket forgatókönyveknek, szinopszisoknak, politikai cselekvési terveknek nevezték. Többségük logikailag nem volt vitatható. Minden ilyen irományban azonban volt egy közös pont: az események másként történtek. Az előfutárnak tekintett Fordulat és Reform vagy a Társadalmi Szerződés címú írások is bőségesen tartalmaztak olyan nézeteket, amelyek messze nem találkoztak a valósággal. A társadalmat gyakran nem a logikusnak, következetesnek túnő viselkedés jellemzi. Ehhez még az is hozzájárul, hogy a véleményformálókat saját kulturális és szociális identitásuk is befolyásolja. Erre utaltunk fentebb, amikor a tudományos megállapításokra is kiterjesztettük a kor és a környezet befolyását. Ma például az euroatlanti civilizáció számára jószerint érthetetlen az iszlám közösségek általunk antidemokratikusnak, korszerútlennek tekintett országlási gyakorlata. Egy másik példa szerint a munka mint kötelezettség, fáradság és áldozat a közösségért, vagy a foglalkoztató szervezet sikeréért megfelelô ellenszolgáltatásért várható csak el. Az altruizmus számunkra az üzleti gondolkodástól idegen. Más kulturális közegben azonban a munka örömszerzés, és nem pusztán javak gyưjtésének vagy a teljesítmények honorálásának forrása.
Tudományos értelemben mindennek hátterében az áll, hogy a megismerés mellett vagy helyett a vezetói logikus gondolkodást nemcsak a megismerések, hanem a felismerések is vezérlik. Ezek közé lehet sorolni a civilizációs és kulturális hagyományok elismerését, valamint az érdekek felismerését. Különösen a politikai vezetés területén szembeszökô, hogy az elemzók többnyire akkor építenek megfigyelésekkel megszerezhető ismeretekre, pl. statisztikákra, ha azzal érvelésüket alá lehet támasztani. Erre példa a nemzetsorssal összefüggố tapasztalat.

Manapság a hazai közgondolkodásban fontos szerepet kap a nemzet jövője, a magyarság fennmaradása. A politikai vezetớk ennek fontossága hangsúlyozásakor szívesen kötik össze a jövớképet a magyarság lélekszámával A nemzet fennmaradását a magyarok számának stabilizálásával vagy növelésével látják biztosítottnak. (Egyes szakértốk nem a lélekszámcsökkenést, hanem az öregedést, a korfa kedvezótlen alakulását tartják a nagyobb gondnak.) Ugyanakkor ezt a megállapítást semmiféle adatszerúséggel, megfigyeléssel nem lehet alátámasztani. Nincs bizonyíték arra, hogy a belátható történelmi távlatban a nagy lélekszámú nemzetek vagy birodalmak jobbak, hatékonyabbak, tartósabbak vagy sikeresebbek lennének, mint a kevés létszámú népcsoportok. A nemzet fennmaradása és lélekszáma közti direkt összefüggés - a kihalást leszámítva - aligha bizonyítható. Egyes népcsoportok, nemzetek (pl. kurdok, örmények, zsidók, cigányok, egyéb diaszpórák stb.) évszázadokon át képesek megórizni nemzeti identitásukat óhazájuktól távol is. Még a földrajzilag meghatározható ország léte sem elengedhetetlen feltétele egy nemzet fennmaradásának. Ha az ország megőrzése vagy a lélekszám növelése a (politikai) vezetók számára relevancia, ezt nem megfigyelésre, hanem valamilyen felismerésre (pl. érdekekre, elkötelezettségre, vágyaikra stb.) alapozták.

\section{A felismerés természete}

A megismerést jelen esszében elkülönítjük a felismeréstől. A megismerés az ismeretszerzés, a felismerés az ismeret-, a tudásalkotás. Amíg a megismerés lényege a tapasztalás, addig a felismerés legfontosabb módszere a gondolkodás. A tapasztalás és a gondolkodás egyaránt a tudás kialakításának alapvetố módszerei, de éppen eltéró voltukból következően lehet megkülönböztetni „termékeiket” is. A tapasztalás terméke a megismerés, a gondolkodás terméke pedig a felismerés. Ugyanakkor tudni lehet, hogy a tapasztalás és a gondolkodás nem szembeállítható, hiszen kölcsönösen építenek egymásra. 
A felismerés a megismerésen túli gondolkodás és kísérletezés következménye, barangolás a nem megismert vagy még nem is megismerhetô világba, az ismeretlenbe. A felismerések egyik fontos alapját szolgáló kutatói kíváncsiskodás, a kísérletezés aktív, környezet-alakító hatású. A megfigyelés (v. ö. tapasztalás) valóságalakító hatása elsődlegesen többnyire passzív. A megismerés a valóság gondolati rekonstrukciója. A logikai igazolás fontos része a premisszákra való építés. Ha azonban ezek iránt is kétség támad, akkor logikai konfúzióról lehet beszélni. A szakácsot és a fogyasztót nem érdeklik az olyan elő́itéletek, miszerint vörös húsokhoz vörös bor dukál. Ettól bátran el lehet szakadni. Maguk az elméleti konstrukciók általában logikai konfúziók, amiket gyakran megfigyelésekkel, megismeréssel lehet rendezni.

A megismerés természetét a tudomány alaposan megvizsgálta, sốt tudományágakat nevezett el róla (episztemológia és empíria). A megismerést egyébként nemcsak logikai, de lélektani és társadalmi összefüggéseiben is értelmezzük. Ezek szerint a megismerés okok és feltételek feltárása, amelyek a hiedelmeket valószínúsítik (bár esetenként nem is a megismerés, hanem a megértés fogalmáról lehet szó). Némileg túlcizellált tudományos álláspontnak (ú. n. erôs program) túnik, hogy a megismerés legyen pártatlan, független. Ebból ugyanis olyan következtetésekre is lehet jutni, hogy pl. a matematika nem alkalmas a megismerés támogatására, mert „pártos” tudomány. Ezt arra alapozzák, hogy a matematika ,jobban szereti" a mennyiségeket, mint a minőségeket. Ugyanilyen elven a logika is ,pártos”, mert abban éppen a minőség kap elsóbbséget a menynyiséggel, a folyamatok az állapotokkal szemben. Más oldalról a pártatlanság nem tud mit kezdeni a társadalmi beágyazódás tényével. Nemcsak a társadalom-, de a természettudományokról is felismerhetô, hogy a kor és a közeg befolyásolta a tudományos tételek születését és kivált alkalmazását (v. ö. korszellem). A tudományos megállapítások felhasználásáról tudni lehet, hogy maguk is tudásalkotók.

Kétséges a megismeréselméletekben, hogy az ember nem lehet megismeró, csak a társadalom, mert a tudás társadalmasodott ismeret. Ez némileg ellentmond a józan észnek (bár ez a tudományban gyakori). Vitatni lehet azt a megismerésre vonatkozó nézetet (vagy követelményt), hogy a magyarázatok (okfejtések) szimmetrikusak, vagyis valaminek az igazságát vagy hamisságát azonos logika mentén lehet (kell) bizonyítani. Ez a tudományos alaptételekre (axiómák, premisszák stb.) nem érvényesíthetô. A megismerés elméletek követése oda is vezethet, hogy egy bizonyítást azért nem fogadnak el, mert az ellenpróbája azonos módszerekkel nem mutatható be. Így pl. a társadalomtudománynak az a része, amely a történelem elemzéséból indul ki, ennek a követelménynek úgy tud eleget tenni, hogy feltételezései, és annak az ellenkezói is igazolhatóak. Ezzel azonban éppen tudományos jellege válik kérdésessé.

Az evolúciós folyamat, amely az élóvilág egyik legáltalánosabb jelensége, számtalan elágazást, logikátlan eseményt, furcsaságot produkált. Az evolúció elméletének szigorú értelmezése alapján ki lehet következtetni, hogy az embernél fejlettebb élólény is kell, hogy legyen (volt, lesz), mert a fejlódés nem állhat meg. Ez a gondolkodás vezetett el a „fejlettebb" társadalmak létrehozhatósága elméleteihez.

Szemezgetéseink csak arra irányultak, hogy rávilágítsunk: bár a megismerést igen gazdag elméleti köret övezi, ezek megállapításai gyakran csak öncélúnak tûnhetnek.

A megismerésben, a premisszák elfogadásában helye van a tekintélyelvnek, a hivatkozásoknak. Nagy szerepet kap mások vélekedése, azok elfogadása, vitája, kritikája, továbbfejlesztése. A vita egyébként is az értelmiség lételeme. A logikai elégséges alap törvénye (lex principium rationis sufficientis) a tudományos bizonyításokban gyakran azt jelenti, hogy más tudósok által igazolt tételekból levezetve igazoljuk az új megállapításokat. A megismerés ezek szerint tudományos összteljesítmény. A megfigyelésekból és a már mások által megfogalmazott tételekbő́l következtetés útján is lehet felismerésekhez jutni.

A felismerésekben ez a másodlagos, származékos mozzanat esetenként nem azonosítható. Az előzmények, tekintélyek és megfigyelések helyébe a felismeró tudományos szakértelme, felelóssége lép. A felismerés eleinte nem tudományos megállapítás, hanem csak vélekedés. Ennek alapja a kíváncsiság, a kételkedés, a tapasztalás, a magyarázatkeresés, az emberi meggyőződés, hogy minden másképp is lehet. Nincsenek olyan szabályok a felismerések sikerességére, igazságtartalmára, amelyek garantálják azok helyességét. Newton számára a fáról leesố alma a tömegvonzás felismerését hozta (amelyet bizonyítania kellett). Az emberek többségének azonban a fejére esô alma nem jelent tudományos inspirációt. Newtonnak is át kellett esnie a fentebb vázolt, minden tudományos megállapításra érvényes procedúrán, így különösen a (puhább) bizonyításon. A tudást, amelyhez akár megismerés, akár felismerés révén jutnak el, igaz (bizonyított) hiedelemnek lehet tekinteni. A megismerés ebben a megközelítésben tartalmazza az igazság bizonyítását (vagyis tapasztalati tényét) is, a felismerés azonban - legalábbis születésekor - még nem ilyen. Más a kiindulópontjuk. 
A felismerés a tudományos elemzések innovatív részéhez tartozik. Nem mintha a megismerés önmagában nem lenne innovatív, de erról tudni lehet, hogy gyakran nem biztosít tudományosan értékelhetô eredményt. A kvantitatív elemzések alapjául szolgáló adathalmazok értékes kiindulópontok, de - tudományterületünkön - ritkán végeredmények. Önmagában persze az adatsoroknak, megfigyelési jegyzókönyveknek is van tudományos értékük. Ha helyes annak meghatározása, hogy mit és hogyan figyelnek meg, akkor igen jelentôs, innovatív tudományos eredményról is lehet a megfigyelések kapcsán beszélni. A megfigyelés tárgyának és módszerének meghatározása azonban nem azonos a megfigyelés eredményével. Az első kvalitatív, innovatív feladat, a második pedig a kvantifikálást valósítja meg (ideértve a nem adatszerúen rögzíthető, jelenségeket leíró megfigyeléseket is). Ez is lehet tudományosan értékes, sốt igen sok esetben ez lehet a megállapítások kiindulópontja. Érdemes azonban emlékeztetni arra, hogy a társadalomtudományokban használt megfigyelési adatok többnyire statisztikai jellegúek. Ezeket hozzáértő emberek szinte mindenre felhasználhatják. $\mathrm{Az}$ adatszerúséget gyakran keverik a tényszerúséggel. Amire adatok utalnak, az még egyáltalán nem bizonyított, hogy tény, objektív állapot vagy folyamat lenne.

A tudományos munkák természetét bizonyos értelemben két csoportba lehet sorolni. Az elsố a meglévő, de eddig kellóen meg nem közelített ismeretek, tudásbázisok ki- és átalakítását, valamint rendezését jelenti, amelynek révén új tudományos megállapítások tehetốk. Ezek sorába tartoznak a megfigyelések is. A második új, az ismert módszerekkel, adatokkal meg nem alapozott vagy meg sem alapozható megállapítások, összefüggések feltárása. Ezek mögött állhatnak természetesen a megismerési folyamat eredményei is. A lényeges különbség azonban az, hogy a felismerések nem közvetlenül következnek az ismert vagy a megszokott módszerekkel megismerhető valóságból. A felismerés igen nagy mértékben kreatív, szellemi tulajdonság, amely nem feltétlenül logikai posztulátumok eredménye vagy következménye. A megismeréssel szemben a felismerések nem kell, hogy eleget tegyenek a fentebb szemelvényesen bemutatott elméleti követelményeknek. Sok, igazán nagyszerú felismerés lényege éppen a közvetlen előzmények hiánya, a kreatív elme nagyszerú teljesítménye. Tipikusan ilyenek a rendszerparadigmák, alapvetések, axiómák, az axiológiai megállapítások, a morális alapvetések, a premisszák, és többnyire ilyenek maguk a tudományos fogalmak, elnevezések is.

A felismerések egyik problémája azok eredetisége, az elsőség. Ha valaki felismerésnek vél olyasmit, amire már más is rájött, sốt bizonyította is, az nem jelent tudományos hátrányt. (Etikailag és üzletileg más a helyzet.) Mások felismerésének megismétlése egyrészt megerôsító jellegú lehet, másrészt, ha a felismeréshez eltérô úton jutottak, akkor bizonyító hatású is. A mi szempontunkból azonban a felismerés elsôsége a tudományos értelemben közvetlen elôzmény nélküli ismeretet jelent.

A felismerés mint alkotó folyamat értelmezéséhez eredményesen lehet használni a megvilágosodás kifejezést is. Ez a szó jól tükrözi azt az állapotot, amikor az ember sötétben tapogatózva nem igazodik el, de egyszerre csak fény gyullad ki az értelmében, és meglátja - felismeri - a körülötte lévő jelenséget, dolgok, folyamatok elhelyezkedését, természetét. Ennek alapján akár el is lehet igazodni köztük. A felismerést ebben az értelemben metodológiai, módszertani problémának is lehetne tekinteni. Arról van szó, hogy miként oldanak meg egy fontos problémát: az új ismeretek megalkotását.

A felismerés, megvilágosodás pillanatát szokták heuréka -élménynek nevezni. (A legenda szerint Arisztotelész a fürdókádba csobbanva jött rá (ismerte fel), hogy a folyadékba merülő test tömegvesztése azonos a test térfogatával. Ezen felismerését akarta közölni a világgal, amikor felkiáltott: rájöttem!) A felismerés azáltal, hogy gyakran nem rendelkezik ismert logikai elózményekkel vagy megfigyelésekkel, gyakran meghökkent, kétségeket támaszt. A felismerés ahhoz, hogy tudományos megállapítássá váljék, ugyanúgy igényli a bizonyítást, mint a megismerésen alapuló megállapítás. A felismerés akár meg is előzheti a megfigyelést, ebben az esetben a megfigyelés (pl. kísérletezés) már a felismerés bizonyításának eszköze.

A felismerés, megvilágosodás, ráébredés, heurékaélmény jelen írásban ugyanazt jelenti. Mentális pillanatról vagy folyamatról van szó, amelyben a gondolkodó ember a meglévő jelenségek alapján felismer valamit, aminek a természetét korábban nem ismerte. A felismerés ebben az esetben nem szükségszerúen rendelkezik közvetlen tudományos előzménnyel. Felismerés az is, ha a kutató valami olyan összefüggést, jelenséget hoz létre (akár csak gondolatilag), aminek saját tudatában és tudatosan nincs elózménye. Amennyiben a szakmájában, tudományterületén elég jártas egyénról van szó, akkor feltételezhetô, hogy nemcsak a saját tudatában, hanem az általános tudományos, szakmai ismeretek közt sincs előzménye, közvetlen forrása felismerésének (mert arról tudna). A felismerés tehát maga a kreativitás, a mentális alkotás, az eredeti innováció. Természetesen felismerést nem csak tudományos értelemben lehet tenni. 
A felismerés és a megértés szoros kapcsolatban állnak. Mindkét esetben összefüggések, viszonyok kerülnek az ember tudatába. A felismerés nem követel meg logikai előzményeket. A megértésnek viszont éppen az a lényege, hogy egymással eddig nem összekapcsolt, bár ismert jelenségeket köt össze a tudat.

A megismerés és felismerés szétválása a valóságban elég ritka, akár a tapasztalás és a gondolkodás elkülönülése. A két logikai mozzanat és elemzési folyamat kapcsolódik, keveredik, összefonódik. A felismerés elkülönítése, önálló kezelése azért került figyelmünk középpontjába, mert a társadalomtudományok ismeretszerzési és cselekvési gyakorlatában a megismerés mellett a felismerés igen erőteljes. Annak magyarázatát, hogy miért pusztult ki az inka vagy a korai khmer civilizáció, legalább annyira építhetjük megismerési, mint felismerési eredményekre.

A felismerések tudományos prezentálásuk során nem rendelkeznek olyan elfogadott, sốt bizonyító erejünek tekintett instrumentumokkal, mint pl. adatszerúségek, mérések, jegyzókönyvek, hivatkozások stb. Ezek hiányában hajlamosak lehetünk a felismerések értékében kételkedni. Ha például egy tudományos értekezés nem tartalmaz releváns szakirodalmi utalásokat, eszmei forrásokat, statisztikai adatokat, kísérleti jegyzókönyveket vagy mérési eredményeket, akkor azt buzgó opponensek elmarasztalják. Jelen írásunk éppen ezzel a problémával foglalkozik. A felismerés nem igényli ezeket az eszközöket, bár éppenséggel támaszkodhat is ilyenekre.

A tudományban egy bölcs megállapítást akkor szoktak megalapozottnak tekinteni, ha azt bizonyítják vagy többen is kimondják. Ha a kimondó sokaság még reprezentatív is, akkor már tudományos eredményként is el szokták fogadni. Egy ember bölcsessége vagy felismerése ritkán érdemel figyelmet. A kutató, a bölcs felismerését csak kivételesen, többnyire utólag szokták tudományos eredményként elfogadni.

\section{A felismerés értelmezése}

A felismerés, mint a valóság megismerésére irányuló gondolkodás, meglehetôsen rejtélyes folyamat. Az emberi képességek igen nagy szerepet játszanak abban, hogy ki alkalmas új felismerésekre. Mondhatni azt is, hogy a tudományban a zsenialitás éppen azt a képességet jelenti, hogy valaki egészen eredeti, akár kevés előzménnyel rendelkezô felismerést tesz. Ilyenhez természetesen meglehet, hogy valaki sziszifuszi munkával, évtizedes kutatással, számtalan próbálkozással jut el. Mindez nem jelenti zsenialitásának gyengeségét. A lényeg a felismerési folyamat és annak eredménye.
Nem alaptalanul nevezik a zsenit lángelmének: jellemzője a fellángolás, a felvillanás, ami a felismerés pillanata.

A felismerések problémája, hogy esetenként az elfogadott bizonyítási módszerekkel nehezen igazolhatók. Az emberré válás fejlódési korszakainak elején ismert három kốkorszak. Ezekre az a jellemző, hogy olyan tárgyi emlékeket lehetett azonosítani, amelyek igazolják: az ember a köveket szerszámként, eszközként használta. Ezt leletek tanúsítják. Pusztán logikai úton el lehet jutni addig a felismerésig, hogy a kókorszakokat megelőzóen, vagy azokkal egy időben kellett lennie „fakorszaknak". Minden érv amellett szól, hogy az emberré válásban a fából készült eszközöknek, szerszámoknak biztos volt szerepe. Erre vonatkozóan azonban közvetlen tárgyi leletek, ismeretek nincsenek, mert a fa nem élte túl azt a néhány tíz- vagy százezer évet, ami e feltételezett korszak óta eltelt. A bizonyíthatóság elfogadott módszere, a lelet tehát nem áll rendelkezésre. Logikailag azonban igazolni lehet, hogy a kóbaltának, a kô lándzsahegynek, vagy a kőből készült nyílhegynek is kellett, hogy legyen nyele, szára. Valószínú, hogy ezeket megelőzte a csak fából készült egyéb vadászóeszköz, mint a bunkó. Ez azonban csak logikai konstrukció. A tudomány a litikumok elótt nem jegyzi a lignikumokat. A leletek hiánya azonban nem azt jelenti, hogy fakorszak nem is volt.

Hasonló módszertani problémák merülnek fel a történelmi folytatólagossággal nem rendelkező társadalmak írott - és teljesen megsemmisült anyagokon tárolt - kulturális örökségével kapcsolatos illetően. Tudni lehet ókori könyvtárakról, de nem lehet igazolni leletekkel, hogy azokban mi lehetett. Mégis vannak ismeretek - feltételezések - ezekre, noha közvetlenül nem igazolhatóak. A felismerés nemcsak a tudástérkép fehér foltjainak kiszínezése, hanem annak besatírozása is lehet. Ilyen esetekben a közvetett - esetleg logikai - bizonyítás módszereire lehet építeni. Nagyjából így alakultak ki a világegyetem, a Föld vagy az élet történetére vonatkozó elsố elméletek is.

Miként a tehetséget is lehet gondozni, a képességeket is fejleszteni, úgy a felismerési folyamatot - melynek természetében sok a tudatalatti, nehezen befolyásolható elem - is lehet támogatni. Az intelligencia, a kognitív képességek és más, jellegzetesen mentális tulajdonságok fejleszthetók. Még a tudatalattinak nevezett, közvetlenül nem hozzáférhető érzékelő-, értékelő és szabályozó-rendszer is befolyásolható tudatos eszközökkel. A tudomány számára igen fontos, hogy ne csak a megismerés, de a felismerés képessége is jelentôs legyen az alkotó emberekben.

A tudományos képzés, a doktori iskolák nagy súlyt fektetnek a megismerési folyamatokra, módszerekre. 
Kutatókat nevelnek úgy, hogy a megismerési technológiát elsajátíttatják, és ezen belül néha érintik a felismerési módszereket is. Erre azonban kevesebb figyelmet fordítanak. Akár a felsőoktatás egészében: a tehetség mint képességgondozás (a mi összefüggésünkben: a felismerés módszereinek tanítása) elenyésző hányada az oktatási rendszereknek. Az egyetemi képzés csúcsa, a doktori iskolák kutatóképzési programjai is a megismerés betanítására irányulnak, de a felismerések módszereit és jelentôségét csak korlátozottan használják. A doktori vizsgák értekezéseiben a hipotézisek azonban arra utalnak, hogy a felismerések helyet kapnak ebben a folyamatban. Erre azt is lehet mondani, a táltosképzés a varázslást, és nem a kutatást szolgálja. Valószínúbb azonban, hogy csak kevésbé ismert és járt utakról van szó.

Természetesen nemcsak a tudósok veszik hasznát a felismerésekhez köthető ismeretszerzési metodológiának, hanem szinte minden embernek jól jön, ha képes erre. A felismerések módszertani támogatása bizonytalan terület. Ezek a problémák a tudományfilozófia szélén, a tudásszociológia partján, de az egyéni és társadalomlélektan, az antropológia és más érintő tudományok határterületein helyezkednek el. A felismerések természetének elemzése a megismerés révén szerzett ismeret megértéséhez kapcsolható, de elérésének útja sok tekintetben eltérō.

A felismerést találóan rokonítani lehet a felfedezéssel. A felfedezés valami olyannak a megismerése, amire talán gyanakodni lehetett. A sejtés anélkül aligha volt igazolható, hogy hirtelen az ismeretlenségból eló ne bukkanjon maga a valóság, az új ismeret. A felfedezés lehet véletlenszerú, elôzmények nélküli is, de alapulhat tudományos megfigyelések, számítások sugallta reményre. Kolumbusz Amerikát nem akarta felfedezni, útját azért szervezte, mert biztos volt abban, hogy a Föld körbehajózható. A felfedezés során a sejtés bizonyossá válik. Az invenció szó eredete egyébként a „kívülról bejött” élményt takarja, vagyis a környezet hatására megszülető újdonságot érteni rajta. Ismertek azonban olyan invenciók is, amelyek csak közvetve köthetők környezeti, tapasztalati hatásokhoz, inkább spekuláció (lásd alább) termékei.

A tudományos megismerés módszertana igen kifejlett, kifinomult. Ehhez képest a felismerési képesség fejlesztése gyerekcipóben jár. Vannak ugyan kreativitást serkentő, alkotást és gondolkodást támogató módszerek, de alapvetően az ember magára marad, amikor valamilyen felismeréshez szeretne, vagy kellene eljutnia. Leginkább a megértési folyamat segít eligazodni a felismerés természetében. A megértés az alapvetôen új, eredeti gondolatokhoz azonban nem elegendő.

A felismerés sok tekintetben több, mint módszer, képesség. Hiába biztatta egy hírhedt politikus az írókat arra, hogy írjanak remekmúveket. A zsenialitáshoz az akarat, a szándék nem elég. Ez a helyzet a felismerési képességgel is. A megismerést sziszifuszi munkával szinte minden közepes tudós elérheti. A felismeréshez valószínú, hogy több kell. Mindazonáltal több olyan módszer is ismert, amelyek segítik a felismerési képesség fejlődését, habár zsenit aligha lehet ezekkel teremteni. A legnagyobb múvészekhez hasonlóan a gyakorlás, az iskolamunkák igen fontosak, de önmagukban nem garantálnak múvészi csúcsteljesítményt. A tehetség olyan természeti adottság, amit gondozni, fejleszteni lehet, de teremteni aligha. Ez a helyzet a felismerési képességekkel is.

\section{A felismerés támogatása}

Az alábbiakban felsorolunk olyan eljárásokat, amelyek segíthetik - noha nem garantálják - a felismerési képességek fejlesztését. Ezek úgy is értelmezhetôk, mint az egyéni gondolkodást serkentő megoldások. Ismertek az úgynevezett kreativitást növelő alkotó technikák. Ezek többnyire csoportos, több személy közös tevékenységére támaszkodó módszerek. Az itt következő lehetôségek ehhez képest az egyéni alkotás, felismerés módszereit ismertetik.

1. Minden tudományos igényú tevékenység kiinduló pontja a gondolkodás. A felismerés, megismerés, megértés közös eleme ez a tudati tevékenység. Tudományos értelemben a gondolkodás kizárólagos emberi sajátosság. Sem az állatvilág, sem a természet, sem a mesterséges eszközök, beleértve a mesterséges intelligenciával rendelkezó lényeket és berendezéseket nem tudnak oly módon gondolkodni, ahogy a tudományos felismerésrôl beszélünk. A tudományos gondolkodás hasznosítja a logika törvényeit, a fogalomalkotási módszereket, a meghatározás és felosztás szabályait, valamint az emberi elme felvillanásait stb. A gondolkodási képesség fejlesztésére számtalan módszer, de elsősorban a tanulás szolgál.

2. A felismerést - mint a tudományos kutatás módszerét - a megismerés testvéreként kezeljük. A megismerés szisztematikus folyamat, amelynek olyan lényeges elemei vannak, mint a tanulás, a felkészülés, a megfigyelés, az értékelés, az elemzés, a bizonyítás stb. A felismerésre ezek a rendezett, kidolgozott szakaszok nem feltétlenül jellemzók. Ebból következóen a megismeréshez hasonló tudástámogató rendszerról nem beszélhetünk a felismerések kapcsán. $\mathrm{Az}$ viszont bizonyos, hogy maga a megismerés a felismerés fontos támogatója.

3. A megismerési folyamat következményeképp kialakul a megértés. Ez azt jelenti, hogy a megismert fo- 
lyamatok, jelenségek, viszonyok természetét képesek vagyunk elhelyezni az általunk ismert szabályok és összefüggések rendjében. Egyben azt is jelenti, hogy a megértés révén elfogadjuk a logikai összefüggéseket, vagy éppenséggel képesek lehetünk éppen azok alapján cáfolni azok helyességét. Ez is támogatja a felismeréseket.

4. A megértés természetének tudományos mintája a matematikai levezetés, a logikai indoklás. Ez gyakran nem más, mint formális vagy dialektikus következtetés. Ha logikailag nem igazolható valamely kapcsolat, akkor azt általában hibásnak minősítjük. A matematika ebben az összefüggésben a logika kifinomult változata, megnyilvánulása. Szinte minden tudomány elfogadja a matematikai érveléseket. Ebben különösen nagy szerepet játszik magának a matematikának a fejlődése. Ennek révén a nem egyértelmú viszonyok is matematikai értelmezést kaptak, mint a statisztika, a valószínúsítés, a sztochasztikus viszonyok, a modellek, a halmazok, a klaszterek, a játékelemek stb. A matematika a formális logika területéról továbblépett az egyéb logikai konstitúciókba, az oksági viszonyok tudományából általában az összefüggések tudománya lett. Éppen ezért a logikai megközelítés, másképp a matematikai kezelhetôség a felismerések komoly támogatója.

5. A felismerés fontos forrása a tapasztalat. Ez a tudományos értelmezéssel nem feltétlenül rendelkezô jelenség igen sok invenció, megérzés forrása. A tapasztalatot lehet tekinteni az ôsi természettudományok alapjának, mint pl. a csillagászat, a navigáció, a topográfia, a gyógyászat, az építészet stb. Ezekben az emberi bölcsesség a tapasztalatokra építve fejlesztett ki olyan eljárásokat, módszereket, ismereteket, amelyeket a kifinomult elméletek is alig tudnak elérni. A vikinghajók külhéjának térgörbéje olyan tökéletes áramlástani felszín, amelyet modellezéssel, szimulációval, térgörbe-analízissel és egyéb, nagy tudású rendszerekkel sem lehet felülírni. Az emberi hozzáértés képes a legtökéletesebb modelleket is pontosítani. Vélhetóen nem arról van szó, hogy a modelleket még fejleszteni kell. Az emberi tapasztalat rendelkezik olyan tulajdonságokkal, amelyeket - legalábbis eddig- nem lehet modellezni. A számítógép mint agymodell igen sok tekintetben legyőzheti az agyat, de elsősorban a kreativitás területén lényeges a különbség az agy (javára) és a számítógép közt.

6. A felismerések nagy támogatói az elméletek. Ezen logikailag koherens és konzisztens nézetrendszereket értünk. Ha valamely témában rendelkezésre állnak jó, kipróbált, bevált elméletek, akkor az új- donságokat, felismeréseket meg lehet kísérelni ezek keretei közé beilleszteni. Ha sikerül valamely jelenséget az elméletek fényében is helytállónak találni, akkor az nagy könnyebbséget ad a körülmények, a múködés, a hatások megértésében. A felismerés lényege ebben az esetben éppen az, hogy az elmélet kiterjeszthetô egy olyan viszonyra is, amire eddig nem alkalmazták. Ez persze forrása lehet az elmélet továbbfejlesztésének is.

7. Az elméletek tudományosan megalapozott, bizonyított, elfogadott nézetek rendszerei. Vannak azonban olyan meggondolások, amelyek nem rendelkeznek mindezekkel a tulajdonságokkal, de a felismerések számára igen hasznosak. Ezek közül néhányat megemlítünk.

- Igen értékesek a koncepciók. A koncepció absztrakt és általános keret, amelybe be lehet illeszteni a valóságot. Más megközelítésben, pl. a társadalomtudományok területén a koncepciókat lehet akár kiforratlan, igazolatlan elméleteknek vagy szándékoknak is tekinteni. A koncepciók mögött tudományosan is értékelhetô háttérismeretek állnak, maguk is tudományos gondolkodás termékei lehetnek. (A szándékokat becsomagoló célzatos vagy politikai koncepcióktól itt tekintsünk el.) Összefüggéseik, állításaik maradéktalan igazolását azonban gyakran nem sikerült hitelt érdemlóen megvalósítani. A gondolkodás serkentésében azonban pozitív szerepet játszanak, keretet adnak. Néha éppen a koncepciók igazolását szolgálják a felismerések, a hiányzó részletek pótlásai.

- A hipotézisek többnyire nem egész gondolati rendszereket, hanem csak bizonyításra váró nézeteket jelentenek. Gyakran egyszerúen feltételezéseknek is tekinthetốk. A hipotézis szinte minden tudományos elôrehaladás fontos része. Természetét tekintve a felismerés elófutára. A hipotézis általában a kutatói sejtés, amely érdemes arra, hogy a tudomány megvizsgálja, körbejárja. Mint ilyen önmagában is lehet egy felismerés, a gyanakvás és a kíváncsiság forrása vagy terméke. Más oldalról a hipotézis a felismerés (vagy a megismerés) kiindulópontja, a kutató céltáblája.

- Még a hipotézisnél is bizonytalanabb a spekuláció. Ezt is feltételezésnek lehet tekinteni, de még gyengébb lábon áll, mint a hipotézis. Sokan úgy vélik, a spekuláció nem is része a tudományos gondolkodásnak, a szónak egyébként negatív csengése is van. A pejoratív értékeléstôl eltekintve a spekuláció azonban logikai előfutár lehet, 
mondhatni első lépés a felismerés felé. A spekuláció nem más, mint logikai kombináció, a megsejtés valószínưsítését szolgáló gondolatsor.

- Érdekes felismerést támogató gondolkodási tényezőnek lehet tekinteni a vélekedést. Ezt a köznapi beszédben hiedelemnek is nevezik. Ez lehet akár csoportos, akár egyéni, akár hosszú múltú, akár pillanatnyi. Jellemzője, hogy nem szükségszerúen rendelkezik megfigyelési vagy logikai kiindulóponttal. A vélekedés gyakran egyszerúen gondolati játék, érdekesség. Sokan például a természetfeletti, paranormális, ezoterikus, transzcendentális jelenségeket, vallási kinyilatkozásokat, amelyekre az ismert megismerési eljárások nem adnak forrást vagy alapot, hajlamosak hiedelmeknek tekinteni. A tudománytörténet még az ilyen ,alaptalan” felismerések, kinyilatkozások, látomások hasznosítására is ismer példákat.

8. A felismerés intellektuális folyamatában igen jelentős az intuíció, a kezdeményező megérzés, a ráérzés. Ha valaki egy szakterülettel, problémával elmélyülten foglalkozik, akkor nemritkán kerülhet olyan helyzetbe, állapotba, hogy megért jelenségeket, összefüggéseket. Ezekre vonatkozóan nem kell feltétlenül egzakt információkkal rendelkezni. Az intuíció ösztönös, tudat alatti elemeket is hordoz, amelyek nem tekinthetók a logikai következtetések világának. Az intuíció forrása gyakran a gyanakvás, mint arra a mindenben kételkedni kell! mondás is utal.

9. A megismerés tudományos apparátusai többnyire egzaktak, algoritmizálhatók és tipizálhatók. A felismerés azonban nem szükségképp rendelkezik ilyen tulajdonságokkal. A felismerési folyamat egészét tekintve rokonítható a mûvészi tevékenységgel, a múvészeti alkotással. Noha a múvészeteknek is vannak iskolái, irányzatai, tanulható fogásai, maga a múvészi alkotó folyamat összességében olyan képességek érvényesülését is jelenti, melyek önmagukban csak tanulással nem teremthetók meg. Miként a múvészetek vezérlőcsillaga az esztétika, úgy a tudomány vezérlő elve a bizonyíthatóság. E tekintetben az autonóm felismerés - akár egy vízió - egyenrangú minden más tudományosan is értékelhetô módszerrel, például a megismeréssel.

10. Igen hasznos, mondhatni elkerülhetetlen segítség a felismerések támogatására a hasonlóságok, esetleg analógiák alapján történó gondolkodás. Ha valamely szakterületen kialakultak elméletek, ismeretek és tapasztalatok, akkor azok termékenyítóleg hatnak nemcsak a rokon, de akár idegen tu- dományterületekre. A rendszertudományok éppen azzal foglalkoznak, hogy a való világ jelenségeinek igen sok közös tulajdonsága van, attól függetlenuil, hogy természettudományi, társadalmi vagy éppen embertudományi problémákról van szó. Ilyen egyezőség pl. a nyílt és zárt rendszerek fogalma vagy a hálózatosodás, amit jószerint az élet minden területén tapasztalni lehet.

11. A hasonlóságok tudományos és gyakorlati hasznosíthatóságának elméleti háttere a tudás természetéből eredeztethetô. Eszerint a tudás nem diszkrét, önálló, individuális ismereteket jelent. Az emberi és a közösségi tudás térhálószerú komplex rendszer. A tudás mint hálózati rendszer rendelkezik a minden hálózatra jellemzô tulajdonsággal. Eszerint a háló több, értékesebb, magasabb színvonalú, mint az alkotóelemek (tudásegységek, szakterületek) összessége. A komplex tudáshálóban vannak hálózati csomópontok, súrúsödési pontok - ez jelent egy szakterületet (vagy információ-központot). A tudás azonban nemcsak a csomópontokat, hanem a tudáshálót összekötô fonalakat, a kapcsolódásokat is jelenti. Ennek hasznosítása pl. az idegen szakterületek ismerete. A hálózat olyan szoros kapcsolatot jelent a csomópontok közt, mely az egész rendszer minőségét megváltoztatja. Minél bonyolultabb, kifinomultabb ismeretrendszerról van szó, annál nehezebb a megismerés, annál inkább fontos a felismerés. A társadalom az ismert rendszerek legbonyolultabbja (más kifejezéssel: legmagasabb mozgási formája). Ebból is következően a megismerés felismerés nélkül nem képes a társadalmi jelenségek természetét kiismerni.

12. A hasonlóságok, párhuzamok alapján történő felismerés egyik intellektuális támogatója a gondolattársítás, a képzettársítás. Ismertek azok az alkotó emberek, akiknek mindenról eszébe jut valami. Ez a felismerési folyamat jellegzetes része. Ha a kutatót erôsen foglalkoztatja egy probléma, akkor különös hajlama van arra, hogy bármilyen más kérdésrôl essék szó, azt gondolatilag összekapcsolja azzal, ami számára a kihívást jelenti. Vannak párhuzamosan rokonítható összefüggések is. Igen híres pl. a matematikus Neumann János analóg levezetése, amelyben az akkor még nem is létező számítógép koncepcióját az agymúködéssel vetette össze. Ma is használunk olyan számítógépes kifejezéseket, amelyek ebból a párhuzamból születtek: memória, memóriakapacitás, múveleti sebesség stb.

13. Igen jelentôsek az általános tudásmegalapozó rendszerek és ismeretek. A rendszerelméletek, a filozófia, a logika, a dialektika, a matematika, az eti- 
ka olyan általános összefüggéseket tartalmaznak, amelyek mindenféle tudást eredményesen támogatnak. Az élővilág területén ilyen általános, konceptuális ismeret pl. az evolúció. A tudományos értékú gondolkodás, így a felismerés is nem csak az említett tudásrendszerek kereteibe illeszthetőek, de éppenséggel ezek támogatják magának a felismerésnek a létrejöttét. Azok a sejtések, amelyek nem felelnek meg a nagy tudásrendszereknek, a mai ismereteink szerint tudományosan nem igazolhatók. A mai tudományelméletek általában materialista és posztmaterialista pilléreken nyugszanak.

14. Az analógiák, hasonlóságok, gondolattársítások természetéből következően megállapítható, hogy ha valaki bármely tudományterületen elmélyült ismeretekkel vagy tapasztalattal rendelkezik, az növeli a képességét és esélyeit arra, hogy a tóle távol álló problémákkal is megbirkózzon. Ismert pl. a mérnöki gondolkodás kifejezés. Ez egyfajta szemlélet, amely bármilyen - akár szociális vagy kulturális - probléma sajátos kezelésére is képessé tehet. Manapság átélhetjük, hogy a társadalmi problémák jelentős részét közgazdasági, szúkebben pénzügyi logikával szokták megoldani. A hadtudományok is régóta viselik a pénzügyi megközelítések bélyegét, holott valószínú, hogy a világ legpazarlóbb és legfeleslegesebb tevékenységéról van szó, tehát holisztikus pénzügyi megközelítésben értelmetlen a hadászkodás. (A politikusok gyakran nemes céloknak tüntetik fel pénzügyi - nyereségszerzô - hadviselési szándékaikat, noha azok éppen financiálisan szoktak igazolhatatlanok lenni.) Korunkban a rendszerelmélet és a kibernetika tölt be generalista tudomány szerepet.

15. Általában a múveltség, a hozzáértés serkentôleg hat a gondolkodásra, legyen az szorosan vett szakterület vagy szakmailag idegen probléma. Ez a felismerést támogató, az általános és szakmai múveltség univerzális felhasználhatóságát erősítő nézet a tudás hálójellegével is összefügg. Az analógiák általánosan - nem csak a tudományban - használt alkalmazása a metafora, a ráutaló, hasonlóságokat hasznosító, gyakran képszerú gondolkodás.

16. A felismerések nagy, történelmileg talán a legrégebbi támogatója a kísérletezés, a próbálkozás. Ez az ,irányított véletlen” felismerés terepe. Maga a véletlen is segíthet a felismerésben, a villámcsapás is hozhat friss gondolatot. Jellemzóbb azonban, hogy a kíváncsi kutató elme megkísérel következtetésekre jutni. Ennek érdekében mesterségesen, időnként a tényleges helyzeteket leegyszerúsítve hoz létre olyan feltételeket, körülményeket, ame- lyek alkalmasak feltételezései igazolására. A próbálkozás még ennél is egyszerúbb folyamat. A próbálkozás lényege annak gyakorlati tesztje, hogy valami elófordulhat, megvalósulhat-e. Ha egy festőmúvész elképzel egy színt, akkor addig kevergeti festékeit, amíg el nem találja azt az árnyalatot, ami benne már ott él. A tudomány is ismer nagyon sok próbálkozásos felismerést. Lényegében a fizika és a kémia története tele van kísérleti vagy próbálkozások szülte eredményekkel. A társadalomtudományok egyik problémája, hogy a kísérletezési lehetôségek korlátozottak. A társadalomtudósok kísérletezési vágyukat a történészek, szociológusok, szociográfusok tapasztalataival - post festa - szokták kielégíteni

17. A modellezés a kísérletezés kifinomultabb, koncepciózusabb változata. A modellek - legyenek azok bármely tudományág segítói - olyan rendezett gondolatok vagy eszközök, amelyek a tudományos következtetések szempontjából a lényeges összefüggéseket tartalmazzák. Ezzel a tisztánlátást, az átláthatóságot segítik, könnyítik a felismerést. A modellezésnek azonban az a kockázata, mondhatni gyengéje, hogy a körülmények és feltételek egy részét elhanyagolja. A modellezés olyan módszer, ami a lényeglátásra épül. Jelentős szerepük lehet a felismerésekben a modellek alkalmazásának. A modellek elméleti konstrukciók, a valóság valamely jelenségének, rendszerének lényeges elemeit kiemelő, elvont összefüggésrendszerek, amelyek a lényegtelennek minősített összefüggéseket elhanyagolják. A modellalkalmazások és -készítések egyaránt lehetővé teszik, hogy a vizsgált problémákat értelmezhetô rendszerbe illesszük, és ezzel elfogadhatóvá és beilleszthetővé tegyük ismereteink tárházába azokat.

18. A felismerések intellektuális alapja, támogatója az érdeklódés. Aligha beszélhetünk olyan felismerésról, melynek megalkotója teljesen közömbös volt eredményei, meglátásai iránt. Az érdeklődés minden tudományos eredmény és tevékenység motorja. Még a véletlen felismerés is érdeklődésre épül. Valószínú, hogy nagyon sok ember fejére esett már fáról alma. A legenda szerint, amikor az érdeklődő Newtont is ez a meglepetés érte, akkor ebból egy felismerés és egy tudományos tan, a tömegvonzás, a gravitáció elmélete következett. Aligha kötötte volna össze Isaac az alma leesését egy tudományos tétellel, ha nem érdekelte volna az egész. $\mathrm{Az}$ érdeklődést tudományos szakmaszeretetnek, elkötelezettségnek lehet tekinteni. Az érdeklődés teremti meg a szellemi érdekeltséget (motiváltsá- 
got, kíváncsiságot). Az érdeklődés népszerú neve a kíváncsiság.

19. A felismerések fontos forrása az intellektuális $b a ́$ torság, a kezdeményezóhajlam. Elsősorban az új problémák iránti fogékonyságról van szó. Ha a tudós talál ilyeneket, akkor személyes attitúd vagy ösztönzés alapján elhatározza, hogy az adott kérdéssel közelebbról is foglalkozni fog, meg akarja ismerni és érteni. A járatlan úton való haladás azonban bátorságot igényel, kockázatai is vannak. A bátorság próbája a kockázatvállalás. A személyes veszélyeztetés mellett az intellektuális kockázatokra utalunk. Ezek közül érdemes kettốt kiemelni. Az egyik a tévedés, a másik az eltévedés veszélye. A felismerések jelentôs része tévedés, melyeket utólag nem lehet megfelelően igazolni. Az eltévedés a kutatók, gondolkodók nagy balszerencséje. Éveket, néha egész életet, sốt generációkat töltenek el olyan probléma megoldásával, amivel nem boldogulnak. Ez persze nem (feltétlenül) eltévedés: eltévedés az, ha rosszul feltett kérdésre keresik a választ. Ha jó a kérdés, de nem tudja megoldani, az nem eltévedés, az megoldatlan probléma. Nem jutnak el sem a felismerésig, sem a megoldhatatlanság bizonyításáig. Tudományos értelemben ez azonban nem meddő befektetés, erófeszítés. Esetleg olyan problémát kutattak, amelynek megoldásához hiányzott még valamilyen köztes ismeret. Ha ez kialakul, akkor majd lesz esély eredménnyel folytatni kutatásaikat.

20. Elég kézenfekvő, de meg kell említeni a hozzáértés szükségességét is. A tudomány tele van laikusok és dilettánsok felismeréseivel. Ezek túlnyomó többsége fabatkát sem ér. Nem mintha a kívülállóknak nem lehetnének nagyszerú felismerései. A dolgoknak mégis az a természete, hogy ha hozzá nem értók agyából pattan ki szikra, akkor az többnyire nem a világítótorony fényét, hanem csak csepút lobbant fel. Kevésbé irodalmi nyelven fogalmazva: a hozzáértés nélküli felismerések valóságtartalma lényegesen alacsonyabb valószínúségú, mint a hozzáértő́ké. A kívülállók közül azonban az amatôröket nem lehet egyszerúen dilettánsnak tekinteni. A nem hivatásos, esetleg szakmán is kívülállók tudományos tevékenységét a bennfentesek hajlamosak gógösen lenézni. A felismerések azonban az amatőrök számára is jelentős tudományos lehetôségeket kínálnak.

21. Tekinthetô általános gondolkodást és kreativitást serkentő módszernek a játék, a kedvtelésból, szórakozásból és örömszerzésből végzett tevékenység. Ehhez hasonló a csevegés, a beszélgetés is. A gon- dolatserkentő módszerek többsége strukturált csoportos, közös magatartás. Ezek a közös tevékenységek olyan képességeket hasznosítanak, aminek a mindennapokban, a professzionális létben gyakran nincs jelentôsége. Ez éppen azzal hat serkentóleg a kreativitásra, hogy a megszokottól eltéró intellektuális és/vagy fizikai képességeket igényel. A felismeréseknek éppen ez lehet az egyik motorja.

22. A felismerések - akár minden más tudományos tevékenység - jelentôs befolyásolója az etika. Ha a társadalomra, a természetre, vagy akár a tudományra nézve a felismerés jelentôs veszélyeket hordoz, akkor etikailag kockázatos. Einstein volt (talán) az elsô, aki az atombomba bevetése kapcsán felvetette a tudomány felelősségét, bár ha korábban is voltak olyan eredmények, amelyek súlyos társadalmi veszélyeket hordoztak. A fejlesztések élvonalába tartozó hadiipar, miközben innovációs szerepe óriási, egyben iskolapéldája a veszélyeztetésnek. Manapság a biotechnológia, közelebbról a génbeavatkozások területénlehettapasztalnijelentősetikaikockázatokat. A tudomány mindezeket a fenntartható fejlődés és a társadalmi felelősség etikai mércéjén keresztül kell, hogy megítélje. Önmagában tehát a károkozás felismerése, a veszélyek elkerülése nem elegendő erkölcsi korlát, ennél szélesebb megítélésre van szükség. Korunk egyik jellegzetessége, hogy a szaktudósok - felelősségi alapon - részt vesznek a társadalmi és politikai vitákban. Mindezek azonban nem a felismerésre, hanem a felismerés gyakorlati alkalmaz(ható)ságára hatnak.

23. Hivatkozni lehet a szerencse hozamára is. Szerencse alatt többnyire az elôre nem látható, számítható események kedvezô kimenetelét szokták érteni. A szerencse a jól sikerült véletlen, ami akaratlan is lehet. Az alkotó folyamatokban azonban a szerencsét lehet támogatni, serkenteni. Ilyen módszer a már említett érdeklődés, a kutatás, a kísérletezés. Nagyobb esélye van annak aranyrögöt kimosni, aki tudja, hol merítse szitáját a patakba. A szerencsét segíti a lehetôségek, az alkalom felismerése és hasznosítása. Elég gyakori vélekedés, hogy valamit akkor kell megtenni, ha majd lehetôség nyílik rá. A szerencse érdekében azonban a lehetőségeket nem várni, hanem keresni kell A felismerést támogató módszerek többsége mint szerencsekovácseljárás is értelmezhetô. A szerencsés kéz többnyire gyakorlott kéz. A szerencsét a gyakorláson kívül más praktikus módszerekkel is lehet támogatni. A hatalom, a befolyás igen erôs szerencsekovácsnak számít, akárcsak az anyagi erô, a pénz. 


\section{A felismerések alkalmazása}

Sem a felismerés, sem a megismerés nem bír jelentőséggel, ha azt a tudományos közvélemény, illetve a gyakorló szakemberek nem ismerhetik meg. A társadalomtudományokban, így a vezetéstudományban fontos, hogy a felismerések érintettjei is tudomást szerezzenek a megállapításokról, eredményekról. Ennek szokásos tudományos formája a publikáció, ami lehet szóbeli, nyomtatott vagy elektronikus változatú. A felismerések természetéból következóen azok közreadása némileg eltérhet az általános tudományos publikációktól. Ezek közismert változata az esszé és a beszéd.

Ez az írás azért is született, mert indokolt egy, a tudományos közvélekedésben meglévố egyoldalúsággal szembeszállni. A tudomány általános szokásai szerint a megfigyelés a világ dolgainak, összefüggéseinek megértését szolgáló alapvetô eszköz. Módszertanilag is jól körülhatárolt a tudósok cselekvési lehetôsége. Indokolt azonban a kevésbé jól konstruált tudományos módszer, a felismerés szerepét is erôsíteni. Mint a bevezetôben is említettük, szúkebb területünkön, a társadalom, és ezen belül is az üzleti tudományokban elég általános, hogy csak akkor tekintenek valamit tudományos eredménynek, ha azt megismerési, sốt sokak szerint megmérési folyamat elôzi meg. E nézet kizárólagosságával is vitatkozunk.

A felismerések fontosságát szükséges hangsúlyozni. A felismerések bizonyítását többnyire megismerési, gyakran mérési feltételekhez kötik. A tudomány számára gyakran a bizonyítás izgalmasabb, sốt akár fontosabb is, mint amit bizonyítani akarnak. Kialakult az a szokás is, hogy meglévố ismereti rendszerekhez, elméletekhez kapcsolják a megállapításokat. Egy ilyen írás, mint jelen gondolatsor, akkor nyerné el a tudományos értekezés rangját, ha jelentős hivatkozási apparátussal, mások vélekedésével való szembesítéssel, pszichológiai kísérletekkel, mérésekkel alátámasztható lenne. Ezek kétségkívül igen hasznos támogatói a tudományosságnak. Kizárólagosságával azonban vitába kell szállni. Értekezésünk lényege a felismerés mint tudományos kutatói módszer természetének vizsgálata és kiállás mellette.

Amegszokott instrumentumokkal felszerelt tudományos értekezés vagy kutatási közlemény mellett nagy jelentőségú az esszé is. Az esszét mint a felismerések megfogalmazásának szokásos formáját értelmezzük. Az esszé múfaj szülőatyjai, Montesquieu és Montaigne a megértés öröme kedvéért, illetve cselekmény nélküli értekezésként, önmaguk gondolatai tisztázására írták meg múveiket. Általában ,igényes elmélkedést”, egyéni hangvételú (nemcsak formai, de tartalmi értelemben is) tanulmányt jelent, ami átmenet a prózai tényirodalom és a tudományos értekezés közt. Az esszé nem igényli mindazokat a tudományos apparátusokat, melyekról fentebb szó esett. Ugyanakkor még az igazán eredeti felismeréseket publikáló, tudományos igényú esszéknek is néhány követelménynek eleget kell tenniük. Így pl. aligha valósítható meg úgy felismerés, hogy annak valamiféle mástól származó gondolati forrása, tapasztalati alapja vagy kísérleti előzménye ne lenne. Ha más nem, hát inspiráló elmék, események állnak mögötte. Amennyiben a tudós felismeréseit esszé formában adja közre, akkor is méltányos (etikus), ha utal azokra a kiinduló vagy befolyásoló tényezókre, körülményekre, forrásokra, amelyek felismerését serkentették. Ha ez mások megállapítása, eredménye vagy kételkedése, akkor plagizálásnak lehet tekinteni, ha az esszé ezeket nem nevezi meg. Elegendő lehet azonban csak a szóhasználattal utalni arra, hogy valami mások véleménye vagy közlése, nem kell feltétlenül a forrásokat is azonosítani.

Az esszé a tudomány számára gyakran apokrif irat. A szakmai Vulgata nem ismeri el értékeiket. Igen kevés az olyan szakfolyóirat, amelyik jó szívvel és nagy tekintéllyel merne esszéket is a tudományos közvélemény elé engedni. Előfordul, hogy az esszéket elkülönítve, önálló rovatban közlik, a „normális” szakcikkektól elkülönítve - ami szerkesztési szempontból érthetô. Szúkebb területünkön, a vezetéstudományban a Harvard Business Review jó példa, hogy az esszé, a hivatkozások mellőzésével közölt felismerések egyenértékúek a forrásmutatókkal gazdagon ellátott tanulmányokkal.

A beszédekben sem szokás hivatkozni, legfeljebb utalni. Tudományos értelemben leginkább konferenciamegnyilatkozások szoktak beszédes formájúak lenni. Amennyiben azonban a felismerés nem tudományos kapacitások, hanem vezetốk gondolati terméke, akkor a beszéd (szónoklat) más jelentőséget kaphat. Ilyenkor a felismerések gyakran mint szándékok, tervek jutnak el az érintettekhez, akár médiaközvetítéssel is. Ezekben nehéz megkülönböztetni a felismeréseket az elhatározásoktól. Mondhatni, hogy a vezetối beszédekben a felismeréseket operacionalizálják, aktivizálják. A (vezetés)tudományi elemzések szívesen építenek vezetối megnyilatkozásokra mint tudományosan is értékelhető forrásokra. Ezek súlya éppenséggel jelentősebb is lehet, mint valamilyen kutatói kútfóból fakadó megállapítás. A vezetéstudományban a stratégiai gondolkodás, tervezés területe az, ahol a megismerés és a felismerés, sốt a szándékok is leginkább keveredhetnek. Nehéz egy vezetối koncepcióból kihámozni, hogy mely részei alapulnak megismerésen, elemzésen, és melyek azok, amelyek ilyen szilárd alapokkal nem rendelkeznek. 
A felismerések bizonyítása gyakran a tanítványok, az utókor feladata. Ez éppen abból a helyzetból következik, hogy a felismerés alapja nem feltétlenül a megismerés. Ilyenkor utólag kell megvizsgálni a valóságot, hogy a felismerés helytálló-e. Társadalomtudományok esetében azonban ez nem mindig lehetséges. A politikusok, vezetók és más közvéleményt befolyásoló személyek, köztük gyakran tudósok is hajlamosak vélekedéseket úgy tálalni, mintha azok releváns felismerések lennének. Ilyet üzleti vezetốk is, gyakran tesznek. Ezt a rossz szokást el lehetne azzal is intézni, hogy nem tudományos problémáról van szó. A jelenség társadalmi súlya azonban alaposabb megfontolást érdemel.

A felismerés is tudományosan értelmezhetô, bizonyítható tények, összefüggések megállapításának módszere. Lényege a kreativitásban, az emberi alkotó elme múködésében rejlik, amelyet a tudományossághoz szükséges megoldásokkal kell kiegészíteni. Azok a vélekedések, amelyek ezekkel a feltételekkel nem rendelkeznek, legfeljebb dogmáknak, hittételeknek tekinthetók. A társadalomtudományokra különösen jellemző, hogy a problémák természetére bonyolult, összetett, sokelemes magyarázatok világítanak rá. A jelentôs társadalmi problémákra nincsenek egyszerú, kevés elemből és hatásból álló megoldások sem.

Társadalmi, gazdasági, és ezen belül vezetési problémák megoldására nem csak egy jó megoldás, hanem több is lehet. Ez, ha úgy tetszik, egy általános társadalomtudományi, vezetéstudományi alapvetés. No one best way. A megoldások mindegyike rendelkezik előnyökkel és hátrányokkal. A társadalomtudományokban az „egy igaz út” aligha létezik. Gyanakvóvá kell tennie minden olyan kijelentésnek a tudományt és az érintetteket is, amelyik ezt akarja elhitetni. Éppen a bonyolultság, összetettség okán a megfigyelések, a megismerés szerepe csak korlátozott. Az többnyire a tudós, az elemzó vagy a politikus elhatározásán múlik, hogy milyen tényezóket emelnek ki, figyelnek meg és értelmeznek. Ebben jellemzô a teleologikus, a célok érdekét szolgáló kiválasztás. Miután a komplex, minden tényezôt figyelembe vevô megfigyelés a nagyon bonyolult esetekben jószerint nem is valósítható meg, így a szokásos megfigyelési módszerek mellett más, tudományosan is igényes eljárásokat kell alkalmazni. Ilyennek lehet tekinteni a felismeréseket is.

Amint említettük, a felismerések közreadásának gyakori módja az esszé, a megalapozott gondolat. Ennek az is a sajátossága, hogy nem követeli meg a források és hivatkozások tételes felsorolását. Mi sem állítottunk össze jelen tanulmányunk mögé egy alapos, több oldalt kitevő hivatkozási listát. A szakértô olvasók minden bizonnyal felfedezték, hogy az itt leírt gondolatok közül igen sokat nem mi eszeltünk ki, hanem másoktól vettünk át. Bizonyára olyan olvasók is vannak, akik már a leírtak cáfolatával is tisztában vannak. Alázattal elismerjük, hogy dolgozatunk jelentôs részben mások megállapításait, megismeréseit és felismeréseit is hasznosította. Ahogy József Attila mondja: már százezer éve nézem, amit látok. Annak oka, hogy mégsem készült alapos forrásbemutatás az, hogy éppen a felismerés természetének ismertetését nem akartuk egy másik módszer, a megismerés szokásai szerint illusztrálni. Etikai vétségünket az indokolja, hogy a hivatkozások nélküli közlemények védelmében született írásunkat nem akartuk forrásmunkákkal erôsíteni. Megértést kérünk.

Cikk beérkezett: 2007. 3. hó

Lektori vélemény alapján átdolgozva: 2007. 6. hó
KEDVES OLVASÓ!

NE FELEJTSE EL MEGÚJÍTANI ELÖFIZETÉSÉT

A JÖVÓ ÉVRE IS! 